\title{
Pemodelan Active Magneto-Pneumatics Suspension Sistem Shock Absorber Berbasis Magnet Nd-Fe-B sebagai Pengganti Sistem Pegas pada Kendaraan Bermotor
}

\author{
Dyah Sawitri,* Yerry Susatio, dan Suko Bagus Trisnanto \\ Jurusan Teknik Fisika, Fakultas Teknologi Industri - Institut Teknologi Sepuluh Nopember (ITS)
}

Kampus ITS Sukolilo, Surabaya 61111

\begin{abstract}
Intisari
Telah diaplikasikan magnet sebagai sistem isolasi vibrasi (shock absorber) pada kendaraan bermotor sebagai pengganti sistem pegas yang memanfaatkan gaya tolak antara dua buah magnet sejenis.. Dilakukan pemodelan active magneto-pneumatic suspension untuk mengetahui performansi magnet melalui pendekatan analisisinterpretasi respon suspensi dan distribusi densitas fluks magnetik. Pemodelan terdiri atas model geometrik dan model matematik, terbagi atas komponen suspensi (magnet permanen Nd-Fe-B dan elektromagnet tersusun dalam konfigurasi serial-vertikal sesuai prinsip levitasi magnet berdasar polarisasi), dan komponen kontrol vibrasi (piezoelektrik beserta charge amplifier, PID voltage controller, dan power amplifier). Berdasarkan hasil simulasi, diperoleh bahwa magnet permanen Nd-Fe-B memiliki performansi yang cukup baik dalam sistem isolasi vibrasi pada kendaraan bermotor, ditunjukkan berdasarkan kapabilitasnya dalam mereduksi vibrasi melalui evaluasi transmisibilitas yang relatif kecil dan stabilitas respon suspensi yang relatif stabil. Desain tekanan pneumatik 0,125 bar dan kontrol umpan maju pada active magneto-pneumatics suspension didapatkan nilai transmisibilitas untuk fungsi profil lintasan sinusoidal yaitu $0,9 \%-7 \%$, untuk fungsi profil lintasan bumb berkisar 6,5\%-25\% dan untuk fungsi profil lintasan random mencapai $2,5 \%$.
\end{abstract}

\begin{abstract}
In this paper, the magnet use as an automotive vibration isolation will be explained. It is based on expelling forces that between two similar magnetic poles. A model of active magneto-pneumatic suspension system is developed to simulate the required magnet performance by analysing the magnetic flux distribution and its related suspension response. Both geometrical and mathematical models consist of suspension sub-components (i.e. Nd-Fe-B permanent magnet and electromagnet which are in serial-vertical structure, with refer to magnetic levitation based on polarisation principle) and vibration control sub-components (piezoelectric and its amplifier, PID voltage coltroller, and power amplifier. Results shown that the Nd-Fe-B permanent magnet have a good performance for isolating automative vibration, indicated by the small transmissibility and high stability of suspension response. With a hydraulic pressure of 0.125 bar and a forward control on active magneto-pneumatic suspension system, respected transmissibility values obtained are $0.9 \%$ - $7 \%$ for sinusoidal path profile, $6.5 \%$ $25 \%$ for bump path profile, and $2.5 \%$ for random profile.
\end{abstract}

KATA KUNCI: model active magneto-pneumatic suspensin, magnet permanent Nd-Fe-B

\section{PENDAHULUAN}

Magnet merupakan material penting yang banyak diaplikasikan dalam berbagai piranti mekanik maupun elektronik. Perkembangan teknologi bahan di bidang fabrikasi magnet telah memungkinkan dihasilkannya magnet permanent dengan tingkat energi mencapai 52 MGOe dengan densitas fluks mencapai 1,3 T [1] yang sesuai diaplikasikan dalam sistem dengan beban besar. Suspensi magnetik merupakan salah satu aplikasi magnet dalam sistem isolasi vibrasi. Pemanfaatan suspensi magnetik dalam sistem ini memberikan kelebihan dibanding tipe suspensi lainnya, yaitu

*E-MAIL: joedep.its.ac.id selain implementasinya yang praktis, juga gesekan dan aus dapat diminimalisasi [2].

Vibrasi merupakan permasalahan umum yang dialami oleh sistem yang bergerak atau terkena gaya luar. Salah satu contohnya yaitu vibrasi pada kendaraan bermotor akibat mesin maupun profil lintasan jalan. Sistem suspensi berperan sangat penting untuk mengontrol vibrasi pada kendaraan bermotor sehingga kenyamanan pengendara dapat terjaga. Suspensi aktif (hydraulic dan pneumatic) merupakan teknologi terkini untuk mengatasi masalah fisis ini, di samping aplikasi Dynamics Vibration Absorber (DVA) dalam suspensi pasif. Melihat kelebihan sifat magnet, permasalahan vibrasi pada kendaraan bermotor memberikan peluang implementasi suspensi magnetik aktif sebagai piranti isolator vibrasi.

Berdasarkan latar belakang tersebut, permasalahan yang akan dicari solusi-penjelasannya adalah bagaimanakah pe- 
modelan active magneto-pneumatics suspension dengan dual dynamics vibration absorber, bagaimanakah respon suspensi pada model suspensi tersebut, serta bagaimanakah performansi magnet dalam sistem isolasi vibrasi pada kendaraan bermotor berbasis model suspensi tersebut?

Penelitian ini bertujuan untuk mendapatkan model active magneto-pneumatics suspension dengan dual dynamics vibration absorber, mengetahui respon suspensi pada model suspensi tersebut, dan mengetahui performansi magnet dalam sistem isolasi vibrasi pada kendaraan bermotor berbasis model suspensi tersebut.

Untuk menghindari melebarnya fokus penelitian, pendekatan sistem yang digunakan adalah magnet permanen yang dipergunakan yaitu jenis Neodymium Iron Boron (Nd-Fe-B) dengan melihat beberapa kelebihan properti fisisnya, suspensi yang dimodelkan yaitu sistem seperempat mobil (quarter car model), mengingat penelitian ini difokuskan untuk mengetahui performansi magnet dalam sistem isolasi vibrasi pada kendaraan bermotor, dan pendekatan gas ideal dan kompresiekspansi adiabatik diberlakukan pada properti system pneumatic yang diimplementasikan.

\section{TINJAUAN PUSTAKA}

\section{A. Tinjauan tentang Pneumatik}

Udara bertekanan (pneumatics) banyak diaplikasikan dalam proses di industri. Sistem pnuematik berbeda dengan sistem hydraulik. Perbedaan mendasar keduanya terletak pada properti fluida yang digunakan. Sistem pnuematik menggunakan udara dan sistem hydraulik menggunakan oli [2]. Karena komponen utamanya yaitu udara, dalam sistem pneumatik berlaku persamaan gas ideal,

$$
P V=n R T=\text { constant }
$$

Untuk proses polytropik gas ideal dalam sistem tertutup, hubungan antara tekanan dan volum dapat dideskripsikan dalam bentuk persamaan berikut

$$
P V^{\gamma}=\text { constant }
$$

Dalam sistem pneumatik, energi potensial disimpan berupa udara terkompresi. Salah satu komponen sistem ini yaitu silinder-piston (Gambar 1). Terdapat berbagai tipe dan ukuran silinder. Dengan total beban (termasuk gesekan) dan tekanan kerja yang telah ditentukan, ukuran silinder dapat dihitung dengan menggunakan hukum Pascal, yaitu gaya sebanding dengan tekanan dan luas penampang,

$$
F=P \cdot A_{p}
$$
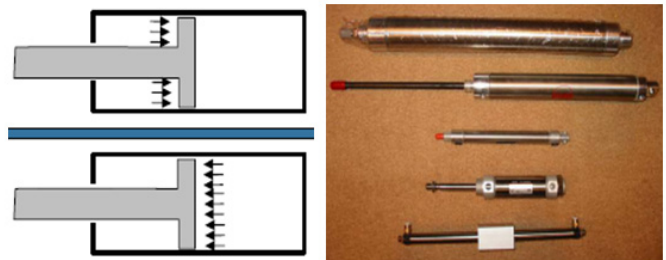

Gambar 1: Silinder-Piston

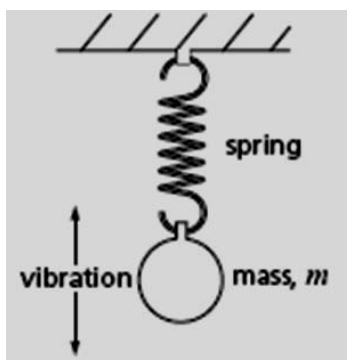

Gambar 2: Sistem pegas massa sederhana

\section{B. Tinjauan tentang Vibrasi}

Secara umum, sistem yang bervibrasi mencakup sesuatu yang menyimpan energi potensial (pegas atau elastisitas), sesuatu yang menyimpan energi kinetik (massa atau inersia) dan sesuatu yang menyimpan energi mengalami penurunan bertingkat (redaman). Salah satu model yang sering digunakan untuk menjelaskan fenomena vibrasi mekanik yaitu sistem pegas-massa (Gambar 2).

\section{Isolasi dan kontrol vibrasi}

Isolasi vibrasi merupakan proses minimaliasasi atau eliminasi pengaruh benda yang bergetar. Fungsi isolator vibrasi yaitu mengurangi besarnya gaya yang ditransmisikan dari sebuah mesin ke pondasinya atau mengurangi besarnya gerakan yang ditransmisikan dari pondasi ke mesin. Suatu ukuran pengurangan gaya atau yang ditransmisikan oleh isolator disebut sebagai transmisibilitas (Gambar 3). Jika sumber vibrasi yaitu gaya eksitasi/disturbans, transmisibilitas (TR) merupakan rasio amplitude gaya yang ditrasnmisikan ke pondasi terhadap amplitude gaya eksitasi, secara matematik didefinisikan sebagai berikut [3],

$$
T R=\frac{F_{t}}{F_{\circ}}
$$

\section{Suspensi aktif}

Salah satu bentuk aplikatif sistem isolasi vibrasi yaitu sistem suspensi pada kendaraan bermotor (Gambar 4). Sistem suspensi didesain agar pengendara merasa nyaman (tidak merasakan getaran berlebih baik dari mesin maupun profil jalan). Sistem suspensi terdiri dari suspensi pasif, semiaktif 


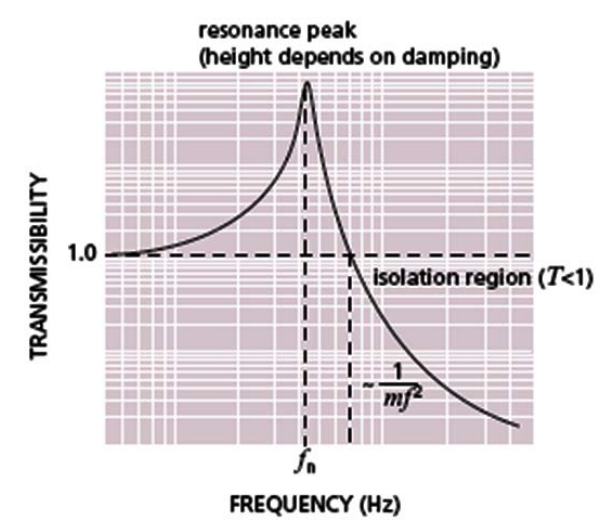

Gambar 3: Kurva transmisibilitas vs frekuensi sistem 1 derajat bebas

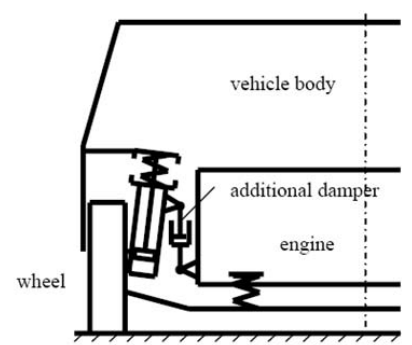

Gambar 4: Model suspensi seperempat mobil

dan aktif. Bila dibandingkan ketiga tipe suspensi tersebut, performansi sistem suspensi aktif ialah yang paling baik [4].

\section{Suspensi magnetik}

Suspensi magnetik aktif merupakan suspensi bebas kontak, sehingga tidak mengalami gesekan atau aus yang merupakan keuntungan paling penting untuk sistem ini. Teknologi ini sekarang banyak digunakan untuk berbagai tujuan industri, dan yang sekarang sedang diterapkan yaitu magnetically levitated vehicle, dan magnetic bearing [2]. Sebagai sebuah isolator vibrasi, suspensi magnetik dapat dinilai serupa sebagai sistem mekanik pegas massa, setidaknya untuk orde 1 . Setidaknya ada dua potensi keuntungan utama meskipun juga terdapat aspek negatif, antara lain; suspensi magnetik nampaknya lebih praktis untuk merencanakan konfigurasi yang menghasilkan frekuensi resonansi rendah (Gambar 5), dan masalah utama terkait resonansi vibrasi yang tidak diinginkan dalam pegas mekanik dan suspensi kawat dapat dihindari [5].

\section{Suspensi pneumatik}

Konstanta kekakuan pegas pneumatik dapat diubah dengan mengubah volume udara dalam pegas tersebut. Dengan mengasumsikan bahwa udara mengalami kompresi dan ekspansi adiabatik nilai kekakuan pegas udara, diberikan sebagai

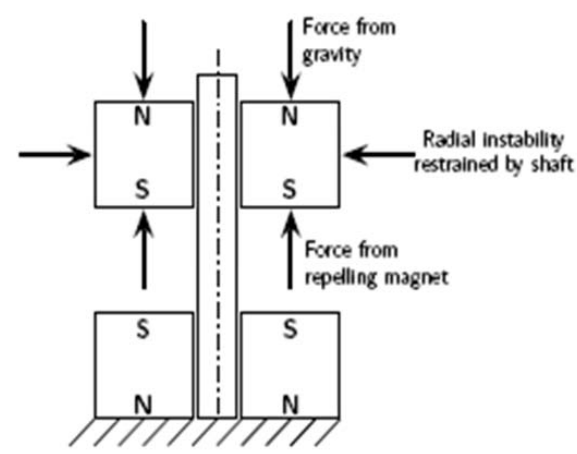

Gambar 5: Penampang melintang dasar pegas magnetik

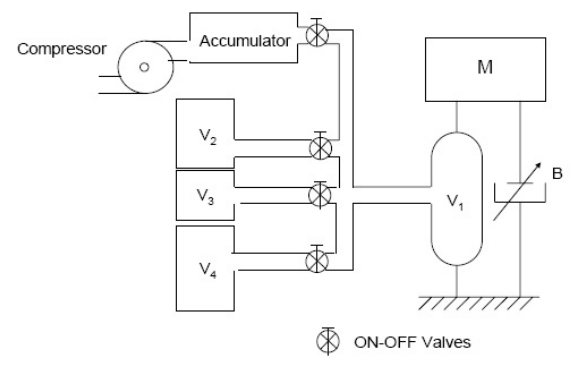

Gambar 6: Pengaturan nilai kekakuan pegas udara

berikut,

$$
k_{p}=\gamma A^{2} \frac{P_{\circ}}{V_{1}}
$$

Dalam suspensi pneumatik tertentu yang masih ada, pegas udara diperlakukan untuk mendapatkan nilai kekakuan dengan memompakan udara keluar atau masuk dalam pegas udara (Gambar 6). Oleh sebab itu, suspensi pneumatik memiliki jangkauan aplikasi yang lebih luas melalui sifaf fleksibilitasnya dalam menghandle beban yang dibutuhkan [6].

\section{Dynamics vibration absorber}

DVA (Gambar 7) merupakan massa sekunder, yang ditambahkan pada sistem asli melalui pegas dan atau peredam. Frekuensi natural DVA diatur sehingga bertepatan dengan frekuensi vibrasi yang tidak diinginkan dalam sistem aslinya. Hal ini mengharuskan adanya komponen tambahan dari struktur total yang menambahkan impedansi input besar terhadap struktur utama. Dengan demikian DVA mampu menyerap energi inersia yang ditransferkan dari struktur utama. Penggunaan DVA sangat menguntungkan karena mobilitasnya, dan kemampuannya untuk tidak berkorporasi dengan struktur. Hal ini mengizinkan absorber disusun tanpa mempengaruhi susunan antara struktur dengan pondasi pendukung sehingga menyediakan struktur yang kokoh dengan pergerakan minimal [7]. 


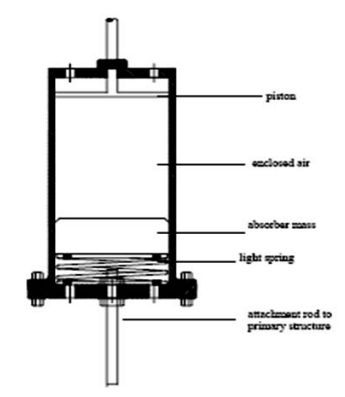

Gambar 7: Dynamics vibration absorber menggunakan udara tertutup sebagai variabel pegas

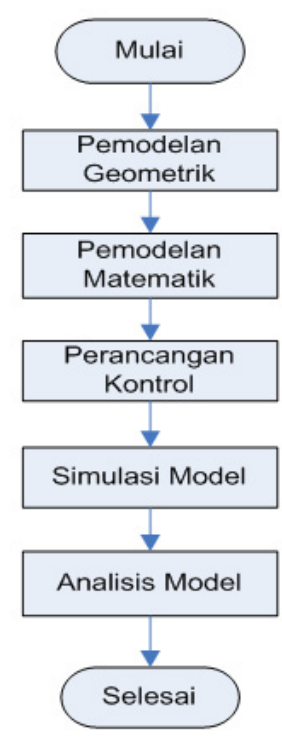

Gambar 8: Diagram alir penelitian

\section{METODE PENELITIAN}

Penelitian tentang suspensi magnet-pneumatik aktif ini terdiri dari beberapa tahapan kegiatan, meliputi pemodelan geometrik suspensi, pemodelan matematik suspensi, perancangan kontrol suspensi, simulasi/uji model suspensi, dan analisis performansi suspensi, yang tersusun dalam diagram alir pada Gambar 8 .

Bagian awal dari pemodelan suspensi magnet-pneumatik aktif yaitu pemodelan geometriknya, yang meliputi pemilihan material suspensi dan penentuan ukuran spasial suspensi.

\section{Pemilihan material}

Pada dasarnya, terdapat dua bahan utama yang digunakan dalam suspensi aktif magnet-pneumatik, meliputi bahan magnet permanen dan bahan magnetik lunak untuk elektromagnet. Properti bahan ini perlu ditinjau dalam pemilihannya terkait nilai konstanta pegas magnetik yang dihasilkan. Untuk komponen pneumatik, digunakan udara bebas dimana hanya besaran tekanan dan volume saja yang diperhatikan, sehingga tidak menjadi perhatian khusus.
Dalam sistem ini digunakan bahan magnet permanen $\mathrm{Nd}$ Fe-B. Bahan magnet Nd-Fe-B dengan densitas fluks remanen 1,52 T dan produk energi maksimum sebesar $440 \mathrm{~kJ} / \mathrm{m}^{3}$ telah dilaporkan [8]. Jenis magnet kelas ini telah tersedia sejak tahun 2004 [9]. Nilai ini mendekati batas capaian praktis magnet $\mathrm{Nd}-\mathrm{Fe}-\mathrm{B}$ sebab produk energi maksimum teoritis untuk kristal Nd1Fe14B1 adalah $510 \mathrm{~kJ} / \mathrm{m}^{3}$. Temperatur operasi maksimum terbatas sekitar $100^{\circ} \mathrm{C}$. Ketika temperatur meningkat, magnetisasi turun hingga koersifitas intrinsik menjadi nol pada sekitar $250^{\circ} \mathrm{C}$. Magnet Nd-Fe-B terbaik yang mampu untuk mentoleransi temperatur sampai $200^{\circ} \mathrm{C}$, menpunyai densitas fluks remanen sekitar $1,2 \mathrm{~T}$ dan energi maksimum sebesar $300 \mathrm{~kJ} / \mathrm{m}^{3}$ pada $20^{\circ} \mathrm{C}$.

Dari sifat mekanis, bahan $\mathrm{Nd}-\mathrm{Fe}-\mathrm{B}$ bersifat rapuh dan keras. Kekuatan tarik sekitar $83 \mathrm{MPa}$ dan kekerasan Vickers sekitar 600, sehingga bahan ini mungkin retak dengan mudah jika diberi perlakuan mekanis berlebih. Bahan Nd-Fe-B merupakan konduktor dengan resistivitas sekitar 1,5 $\mu \Omega \mathrm{m}$ pada temperatur $20^{\circ} \mathrm{C}$, tetapi dengan konduktivitas termal yang kecil sekitar $9 \mathrm{~W} / \mathrm{mK}$.

\section{Bahan magnetik lunak untuk elektromagnet}

Bahan magnetik lunak mempunyai suatu peran pokok dalam banyak sistem elektronik dan elektrik pada masyarakat modern. Bahan ini memperlihatkan sifat magnetis hanya ketika berada pada pengaruh gaya magnetisasi seperti medan magnet yang diciptakan oleh suatu magnet permanen atau arus yang melewati kumparan melingkupi inti magnetik itu.

Perbedaan utama antara bahan magnetik lunak dan keras yaitu perbedaan kekuatan medan koersif; bahan magnetik lunak mempunyai sifat medan koersif rendah, $\mathrm{H}_{c}<1 \mathrm{kA} / \mathrm{m}$. Beberapa sifat bahan magnetik lunak lain bentuk anisotropi rendah, magnetostriksi rendah, kekerasan mekanik rendah dan anisotropy kristal yang rendah pula ([10]. Bahan magnetik lunak dapat digolongkan antara lain Electrical steels (nonoriented dan grain-oriented), paduan Nikel-Besi, ferrite lunak (NiZn dan MnZn), logam-logam amorphous, soft magnetic composites (SMC) dan Construction steels.

\section{Penentuan ukuran spasial}

Ukuran spasial memberikan gambaran tentang dimensi suspensi, yang menyangkut besaran-besaran geometris yaitu panjang suspensi ls, dan internal diameter piston (termasuk diameter magnet permanen), dm. Dengan menggunakan software AutoCAD 2007, dibuat model geometrik suspensi dalam 3D dan 2D, seperti pada Gambar 9. Secara detail suspensi magnet-pneumatik aktif terdiri dari 4 buah magnet permanen $\mathrm{Nd}-\mathrm{Fe}-\mathrm{B}$, yang berfungsi sebagai force balancer dan $d y$ namics vibration absorber, dan sebuah magnet induksi elektrik (elektromagnet) yang terdiri dari kumparan berarus listrik pada suatu bahan magnetik lunak sebagai core-nya sebagai adaptive controller. Terdapat pula hole yang digunakan sebagai output perubahan tekanan pneumatik dalam suspensi untuk dihubungkan ke sensor (piezoelectric). 


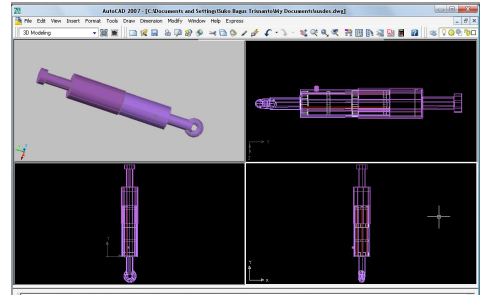

Gambar 9: Desain 3D active magneto-pneumatics suspension

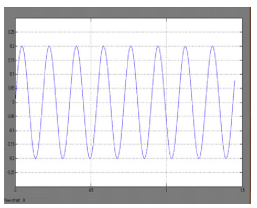

(a)

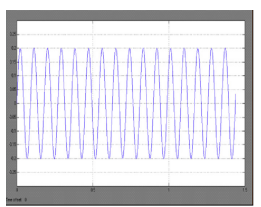

(b)

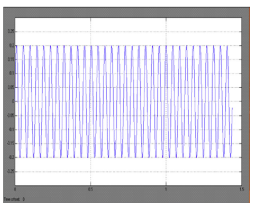

(c)

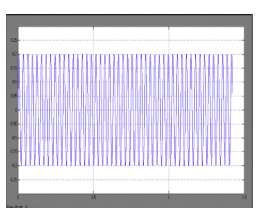

(d)

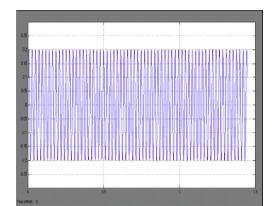

(e)
Gambar 10: Sinyal uji fungsi sinusoidal mode kecepatan 20, 40, 80, 120 dan $160 \mathrm{~km} / \mathrm{jam}$

\section{ANALISIS DAN PEMBAHASAN}

\section{A. Analisis data simulasi model suspensi}

Penentuan respon sistem suspensi yang dimodelkan didasarkan pada uji 3 jenis fungsi profil lintasan (sinyal input), yaitu sinyal sinusoidal, sinyal bumb dan sinyal random. Ketiga sinyal masing-masing akan diujikan terhadap 3 desain kontrol vibrasinya, yaitu kontrol umpan maju, tanpa kontrol, dan kontrol umpan balik. Rasionalisasi terkait pemilihan jenis fungsi uji tersebut sebagai berikut;

- Fungsi uji berupa sinyal sinusoidal bertujuan untuk mengetahui respon sistem suspensi berkaitan dengan gangguan periodik.

- Fungsi uji berupa sinyal bumb (sinyal sinusoidal setengah periode awal) bertujuan untuk mengetahui stabilitas sistem suspensi dan waktu respon transien, identik dengan pengujian dengan sinyal impuls. Di samping itu, pengujian dengan sinyal ini, juga dapat diketahui pengaruh kecepatan terhadap besarnya transmisibilitas. Sinyal bumb ini didapatkan dengan mensuperposisikan 2 buah sinyal sinusoidal, yang salah satunya digeser fasenya sebesar setengah periode sinyal, atau sinyal hanya didefinisikan pada rentang waktu setengah periode, yaitu $\mathrm{y}(\mathrm{t})=\alpha \sin (2 \pi \mathrm{vt})$, untuk $0 \leq \mathrm{t} \leq \frac{1}{v}$.

- Fungsi uji berupa sinyal random bertujuan untuk mengetahui respon sistem suspensi terkait dengan gangguan profil jalan yang tidak diprediksi (acak). Dari

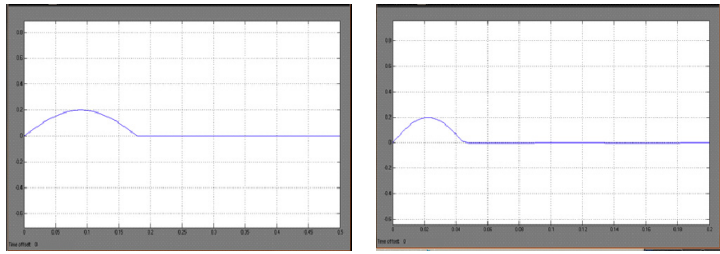

Gambar 11: Sinyal uji fungsi bumb mode kecepatan $20 \mathrm{~km} / \mathrm{jam}$ dan $80 \mathrm{~km} / \mathrm{jam}$

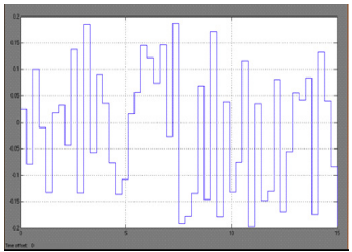

Gambar 12: Sinyal uji fungsi random

respon sini juga akan dapat diketahui nilai transmisibilitasnya. Fungsi random (Gambar 12) tidak dapat ditentukan persamaan matematisnya.

\section{Kontrol umpan maju}

Pada dasarnya, kontrol umpan maju yang didesain dalam ini bertujuan untuk memanipulasi input arus listrik pada komponen elektromagnet berdasarkan fungsi profil lintasan. Fungsi disturbans ini dikorelasikan dengan perubahan tekanan pneumatik pada kolom suspensi sehingga dapat dideteksi oleh sensor. Kontrol umpan maju ini dirancang untuk tekanan pneumatik suspensi sebesar 3 bar. Berdasarkan hasil simulasi respon suspensi untuk tekanan pneumatik 3 bar, didapatkan data grafis sebagai berikut :

- Untuk fungsi uji sinyal sinusoidal dengan 5 mode kecepatan ditunjukkan pada Gambar 13. Dapat diamati bahwa amplitude respon suspensi semakin turun seiring dengan bertambahnya kecepatan.

- Untuk fungsi uji berupa sinyal bumb dengan 2 mode kecepatan ditunjukkan Gambar 14. Dapat dilihat bahwa mode kecepatan $80 \mathrm{~km} / \mathrm{jam}$ memiliki amplitude respon yang jauh lebih kecil dari mode kecepatan $20 \mathrm{~km} / \mathrm{jam}$. Dengan kecepatan $20 \mathrm{~km} / \mathrm{jam}$, dihasilkan amplitude respon suspensi sebesar $18 \mathrm{~cm}$ atau transmisibilitasnya 90\%. Sedangkan, dengan kecepatan 80 km/jam, dihasilkan amplitude respon sebesar $5 \mathrm{~cm}$ (transmisibilitas 25\%). Dengan data ini, dapat diketahui bahwa untuk uji sinyal bumb, suspensi aktif magnet-pneumatik tidak bisa menghandle, terbukti transmisibilitas sistem melebihi batas maksimum yang didesain pada mode kecepatan $20 \mathrm{~km} / \mathrm{jam}$. Dengan uji profil lintasan bumb ini, dapat diketahui pula bahwa sistem suspensi tidak stabil (waktu respon transien mendekati tak hingga) untuk tekanan pneumatik 3 bar. 


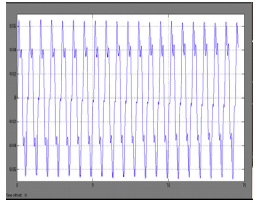

(a)

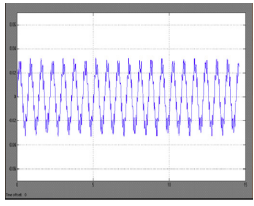

(b)

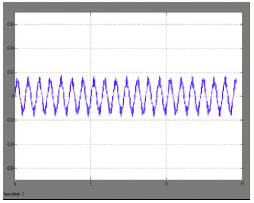

(c)

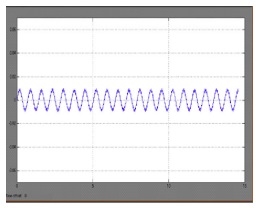

(d)

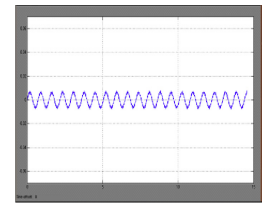

(e)
Gambar 13: Respon dinamik massa utama, terhadap sinyal sinusoidal untuk kontrol umpan maju mode kecepatan 20, 40, 80, 120 dan $160 \mathrm{~km} / \mathrm{jam}$
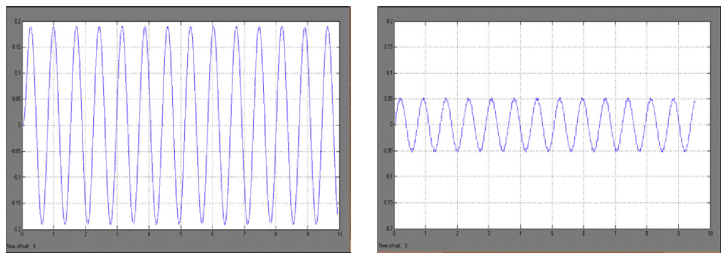

Gambar 14: Respon dinamik massa utama, xb, terhadap sinyal bumb untuk kontrol umpan maju (Po $=3$ bar) mode kecepatan 20 dan 80 $\mathrm{km} / \mathrm{jam})$

- Untuk fungsi uji berupa sinyal random, dapat diketahui respon suspensi bersifat periodik dengan amplitude mencapai $0,8 \mathrm{~cm}$ atau nilai transmisibilitas sekitar $4 \%$. Selama 15 detik selang waktu respon, nilai amplitude semakin besar (sistem semakin tidak stabil).

Berdasarkan data grafis untuk semua respon suspensi (perpindahan massa utama) pada tekanan pneumatik sebesar 3 bar terhadap fungsi uji yang diberikan, dapat digeneralisasi bahwa respon suspensi berupa fungsi periodik dengan transmisibilitas bervariasi antara $4 \%$ hingga $90 \%$. Hal ini menunjukkan dengan kontrol umpan maju, rata-rata respon sistem suspensi masih relatif tidak stabil. Selain itu, kecepatan kendaraan ternyata memberikan pengaruh terhadap besarnya amplitude respon. Kecepatan tinggi ternyata mampu menurunkan nilai transmisibilitas.

\section{Tanpa kontrol}

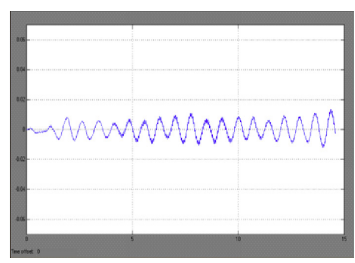

Gambar 15: Respon dinamik massa utama, terhadap sinyal random untuk kontrol umpan maju

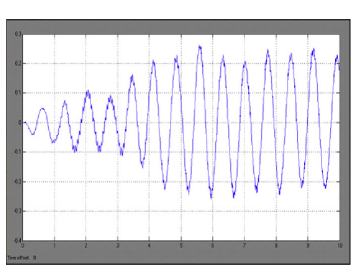

Gambar 16: Respon dinamik massa utama, terhadap sinyal random untuk sistem tanpa kontrol

Untuk mengetahui tingkat efektivitas keberadaan kontrol vibrasi yang diterapkan pada suspensi magnet-pneumatik ini, perlu diketahui respon suspensi tanpa kontrol didalamnya. Respon suspensi tanpa kontrol didapatkan dengan mengabaikan pengaruh input arus listrik pada komponen elektromagnet. Simulasi ujinya serupa dengan yang dilakukan pada suspensi yang dilengkapi kontrol umpan maju.

Berdasarkan hasil simulasi untuk uji suspensi magnet pneumatik tanpa kontrol pada tekanan internal 3 bar, tidak terdapat perbedaan respon amplitude dan transmisibilitas yang signifikan (nyaris sama) dengan respon suspensi untuk kontrol umpan maju, kecuali untuk sinyal uji random.

Respon suspensi terhadap sinyal uji sinusoidal mode kecepatan $20,40,80,120$, dan $160 \mathrm{~km} / \mathrm{jam}$ identik dengan respon serupa pada kontrol umpan maju, demikian pula respon suspensi terhadap sinyal bumb, nilai amplitude responnya juga sama dengan nilai respon pada kontrol umpan maju untuk tekanan pneumatik 3 bar. Yaitu berturut-turut untuk mode sinyal bumb mode kecepatan 20 dan $80 \mathrm{~km} / \mathrm{jam}$ adalah $18 \mathrm{~cm}$ dan $5 \mathrm{~cm}$ (setara dengan transmisibilitas $90 \%$ dan 25\%), sehingga dapat digeneralisasikan pernyataan yang serupa bahwa kenaikan kecepatan kendaraan memberikan pengaruh pada penurunan nilai transmisibilitas getaran.

Berbeda dengan respon suspensi terhadap sinyal sinusoidal dan bumb yang identik dengan respon pada kontrol umpan maju, respon suspensi akibat sinyal uji random (Gambar 16) menunjukkan ketidakstabilan dengan amplitude mencapai 25 $\mathrm{cm}$, setara dengan transmisibilitas $125 \%$. Nilai ini berada di atas desain maksimal amplitude respon.

\section{Kontrol umpan balik}

Analisis respon suspensi untuk kontrol umpan balik diperlukan dalam rangka membandingkan terhadap hasil yang didapatkan dari respon suspensi dengan kontrol umpan maju, sehingga diketahui jenis loop kontrol yang lebih baik.

\section{B. Interpretasi desain kontrol vibrasi}

Untuk kemudahan pembacaan data dan analisis, seluruh hasil simulasi untuk ketiga hasil respon ditampilkan dalam satu Tabel 1.

Berdasarkan data grafis, baik kontrol vibrasi dengan loop umpan balik dan loop umpan maju memiliki tingkat performansi yang sama. Karena itu, tidak menjadi permasalahan 
TABEL I: Parameter parameter tiga jenis kontrol, tanpa kontrol, umpan maju dan umpan balik.

\begin{tabular}{lcccccc}
\hline \hline Fungsi & \multicolumn{3}{c}{ Tanpa Kontrol } & \multicolumn{2}{c}{ Umpan Maju } & \multicolumn{2}{c}{ Umpan Balik } \\
Uji & $\mathrm{X}_{b o}$ & TR & $\mathrm{X}_{b o}$ & $\mathrm{TR}$ & $\mathrm{X}_{b o}$ & $\mathrm{TR}$ \\
& $(\mathrm{cm})$ & $(\%)$ & $(\mathrm{cm})$ & $(\%)$ & $(\mathrm{cm})$ & $(\%)$ \\
\hline $\mathrm{S}-20$ & 0.065 & 32.5 & 0.065 & 32.5 & 0.065 & 32.5 \\
$\mathrm{~S}-40$ & 0.03 & 15 & 0.03 & 15 & 0.03 & 15 \\
$\mathrm{~S}-80$ & 0.016 & 8 & 0.016 & 8 & 0.016 & 8 \\
$\mathrm{~S}-120$ & 0.01 & 5 & 0.01 & 5 & 0.01 & 5 \\
$\mathrm{~S}-160$ & 0.008 & 4 & 0.008 & 4 & 0.008 & 4 \\
B-20 & 0.18 & 90 & 0.18 & 90 & 0.18 & 90 \\
$\mathrm{~B}-80$ & 0.05 & 25 & 0.05 & 25 & 0.05 & 25 \\
Ran. & 0.008 & 125 & 0.25 & 4 & 0.008 & 4 \\
\hline \hline
\end{tabular}

dalam implementasi jenis loop kontrol pada suspensi magnetpneumatik ini, terkait pemilihannya.

Kontrol vibrasi diaplikasikan dalam rangka mengendalikan nilai amplitude respon (transmitsibilitas). Dalam hal ini, sistem suspensi didesain dengan kontrol umpan maju dengan hipotesis awal bahwa secara teoretis nilai error dapat diminimalisasi hingga nol dibanding dengan kontrol umpan balik yang menyisakan error steady state. Uji sistem tanpa kontrol dilakukan untuk mengevaluasi efektivitas implementasi kontrol vibrasi tersebut. Berdasarkan hasil simulasi, didapatkan kesimpulan bahwa kontrol vibrasi tidak memberikan pengaruh signifikan terhadap pengendalian transmisibilitas kecuali untuk fungsi lintasan acak. Melihat hasil ini, terdapat dua hal yang perlu dievaluasi, yaitu model suspensi dan loop kontrol vibrasi sebagai bagian dari interpretasi desain kontrol vibrasi pada suspensi aktif magnet-pneumatik ini.

\section{Evaluasi model suspensi}

Model suspensi yang mencakup komponen-komponen suspensi beserta geometri spasialnya merupakan salah satu pertimbangan dalam menentukan desain kontrol vibrasi, di samping terkait faktor kenyamanan (nilai transmisibilitas vibrasi). Berdasarkan desain suspensi, diketahui bahwa ukuran spasial suspensi dapat identik dengan tabung tinggi $\pm 40 \mathrm{~cm}$ dan jari-jari $\pm 7 \mathrm{~cm}$ yang mampu menahan massa sebesar \pm 400 $\mathrm{kg}$. Dengan memperhatikan model geometrik ini, sistem kontrol vibrasi didesain agar output respon vibrasi massa utama (transmisibilitas) tidak lebih dari $16 \mathrm{~cm}(\mathrm{TR}<<80 \%)$.

\section{Performansi komponen suspensi}

Sebagaimana disebutkan, komponen suspensi aktif megnetpneumatik ini terdiri dari dua elemen utama yaitu DVA meliputi 2 buah magnet permanen, dan elektromagnet. Pada kasus ini, respon vibrasi terkait DVA dan elektromagnet tidak disimulasikan. Namun, berdasarkan penyelesaian matrik persamaan dinamik suspensi, dapat diketahui respon masingmasing komponen suspensi terdefinisi dalam domain Laplace seperti ditunjukkan persamaan berikut:

$$
W(s)=\frac{.480 e^{11} \cdot s^{4}+.311 e^{15} \cdot s^{2}+.278 e^{16}}{.194 e^{5} \cdot s^{8}+.276 e^{9} \cdot s^{6}+.107 e^{13} \cdot s^{4}+.631 e^{15} \cdot s^{2}+.279 e^{16}}
$$

Dari persamaan di atas, dapat ditarik kesimpulan bahwa respon vibrasi magnet permanen maupun elektromagnet tidak hanya dipengaruhi oleh fungsi profil lintasan jalan, tetapi juga terpengaruh oleh input arus listrik yang masuk pada komponen elektromagnet.

\section{Performansi komponen kontrol}

Berdasarkan hipotesis awal, keberadaan kontrol vibrasi seharusnya mempunyai dampak signifikan terhadap kontrol output respon suspensi. Namun, sesuai dengan hasil evaluasi transmisibilitas dan stabilitas suspensi, tidak ada perbedaan mencolok antara sistem suspensi yang dilengkapi dengan kontrol vibrasi dengan sistem suspensi tanpa kontrol, kecuali pada uji sinyal random. Berikut evaluasi performansi komponen kontrol yang meliputi sensor, kontroller dan aktuator. Evaluasi dilakukan dengan memberikan uji impuls pada fungsi transfer setiap komponen, lalu ditentukan nilai output untuk $\mathrm{t}$ $=\tau$.

\section{Sensor}

Sensor piezoelektrik beserta charge amplifier-nya mempunyai fungsi transfer yang relatif kompleks, mengubah variabel input tekanan pneumatik menjadi variabel output tegangan. Adapun korelasi perubahan tekanan pneumatik terhadap perubahan posisi magnet permanen base bawah (identik dengan fungsi profil lintasan), juga memiliki fungsi transfer yang relatif kompleks seperti ditunjukkan persamaan berikut:

$$
G s(t):=(-1.20) e^{(-455) t}+1.2 e^{\left(-.169 e^{4}\right) t \cos \left(.169 e^{6} t\right)+447 e^{\left(-.169 e^{4}\right) t} \sin \left(.169 e^{6} t\right)}
$$


Diketahui bahwa time constant relatif kecil yaitu 1/455 s, jika dimasukkan pada persamaan fungsi transfer untuk sensor tersebut didapatkan $\operatorname{Gs}(\tau)=6,77 \mathrm{~V}$. Dengan demikian, sensor piezoelektrik dan rangkaian pengondisi sinyal efektif digunakan sebagai komponen transducer dalam kontrol vibrasi ini.

\section{Kontroller}

Pemilihan mode kontrol merupakan hal yang penting dalam kontrol vibrasi, dipilih mode kontrol PID sesuai dengan persamaan:

$$
G c(t)=2 . \Delta(1, t)+2 . \Delta(t)+.500
$$

Evaluasi kontroller ini menggunakan uji impuls 1 volt, diketahui bahwa kontroller tidak mempunyai time constant $(\tau=0)$. Dengan men-substitusikan nilai tersebut, didapatkan $\mathrm{G}_{c}=0,5 \mathrm{~V}$.

Bila dievaluasi berdasarkan respon suspensi yang sifatnya periodik, mode kontrol ini perlu ditinjau ulang. Sekalipun, pada dasarnya secara teoretis mode kontrol ini menurunkan ripple dan mempercepat off-set, beberapa bentuk sinyal uji suspensi masih didapatkan ripple dengan amplitude lebih dari 5\%. Mengingat penentuan parameter kontrol berdasarkan teknik optimasi terkait komponen elektromagnet, kompleksitas fungsi transfer input arus listrik terhadap output vibrasi massa utama perlu diperhatikan pula.

\section{Aktuator}

Aktuator yang digunakan dalam kontrol vibrasi yaitu penguat daya (penguat tegangan), yaitu mengubah input tegangan menjadi arus listrik. Berdasarkan penelitian sebelumnya, didapatkan fungsi transfer untuk power amplifier sebagaimana tercantum di bawah ini.

$$
G a(t):=803 . e^{(-110) t} \cdot \cosh (95.5 t)-924 . e^{(-110) t} \sinh (95.5 t)
$$

Adapun evaluasi uji impulse 1 volt, dan time constant relatif kecil yaitu 1/110 s diperoleh output aktuator pada waktu ini sebesar $\mathrm{Ga}=80,3 \mathrm{~A}$. Dengan demikian, sebagaimana performansi ini, power amplifier ini juga dapat digunakan aktuator pada kontrol vibrasi.

\section{Evaluasi loop kontrol vibrasi}

Sebagaimana dijelaskan di awal, implementtasi kontrol vibrasi dalam kasus ini efektif untuk sinyal uji random, sedangkan terhadap sinyal uji yang lain, responnya identik. Adapun evaluasi terhadap loop kontrol, tidak ada perbedaan respon suspensi antara implementasi loop kontrol umpan maju maupun umpan balik. Meninjau hipotesis awal yang menyatakan bahwa performansi loop kontrol umpan maju lebih baik, setidaknya terdapat beberapa rasioanalisasi terkait kesamaan respon suspensi kedua loop kontrol ini dan terhadap sedikitnya perbedaan dengan sistem suspensi tanpa kontrol, sebagai berikut:
1. Pada dasarnya komponen kontrol untuk loop umpan maju dan umpan balik adalah sama, yang berbeda yaitu fungsi transfer perubahan tekanan pneumatik terhadap posisi magnet permanen atau massa utama. Perbedaan fungsi transfer ini seharusnya menyebabkan perbedaan fungsi input sensor. Dimungkinkan pula fungsi transfer ini menghasilkan nilai output yang relatif kecil untuk beberapa fungsi input.

2. Fungsi transfer antara input arus listrik terhadap output perpindahan massa utama relatif kompleks dengan selisih orde antara numerator dan denumerator yaitu 4 orde dan selisih koefisien suku masing-masing orde yang relatif besar, dimungkinkan menjadikan berbagai nilai input memiliki korespondesi output yang relatif kecil, atau dapat didekati dengan nilai nol $(A(s) \cdot I(s) \approx$ $0)$.

3. Terkhusus evaluasi terhadap sinyal uji random, perubahan nilai amplitude yang acak terhadap fungsi waktu dimungkinkan terjadi superposisi sinyal pada summing point dengan nilai output $A(s) . I(s) \neq 0$

Mengingat keterbatasan ini, validasi lanjut terkait rasionalisasi hasil simulasi terhadap hipotesis awal perlu dilakukan, sehingga alasan teoretis tersebut dapat diterima.

\section{SIMPULAN}

Berdasarkan hasil analisis data simulasi dan interpretasinya, dapat dirumuskan beberapa kesimpulan antara lain:

- Telah dilakukan pemodelan active magneto-pneumatics suspension dengan dual dynamics vibration absorber yang terdiri atas model geometrik dan model matematik, terbagi dalam 2 kategori; komponen suspensi yang terdiri atas magnet permanen $\mathrm{Nd}-\mathrm{Fe}-\mathrm{B}$ dan elektromagnet tersusun dalam konfigurasi serial-vertikal, dan komponen kontrol vibrasi terdiri atas piezoelektrik beserta charge amplifier, PID voltage controller, dan power amplifier,

- Magnet dalam sistem isolasi vibrasi kendaraan bermotor memiliki performansi yang cukup baik, ditunjukkan berdasarkan kapabilitasnya dalam mereduksi vibrasi melalui evaluasi transmisibilitas yang relatif kecil dan stabilitas respon suspensi yang relatif stabil.

\section{Ucapan Terima Kasih}

Kepada LPPM ITS yang telah membiayai riset ini melalui Dana Program Unggulan Mandiri (PUM) ITS Tahun 2011 Sesuai Surat Perjanjian Nomor: 781.13/I2.7/PM/2011 tanggal 2 Mei 2011. 
[1] MAGCRAFT, Permanent Magnet Selection and Design Handbook (USA: MAGCRAFT Advanced Magnetic Materials, 2007).

[2] T. Namerikawa, and M. Fujita, T.IEE Japan, 121-C (6) (2001.

[3] K. Ogata, System Dynamics (Prentice Hall-Pearson Education International, New Jersey-USA 1998).

[4] S. Segla, and S. Reigh, S., Optimization and Comparison of Passive, Active and Semi-Active Vehicles Suspension System, 12th IFToMM World Congress, Besanon (France), June 18-21,2007.

[5] R.W.P. Drever, Technique for Extending Interferometer Performance Using Magnetic Levitation and Other Methods, Proceedings of the International Conference of Gravitational Waves: Source and Detector, Cascina-Italy March 19-23, 1996.

[6] H. Deo, and N.P. Suh, Pneumatics Suspension System with Independent of Control Damping, Stiffness and Ride Height, Proceedings of ICAD 2006 4th: International Conference on Association
Design, Firenze June 13-16, 2006.

[7] C. Ting-Kong, Design of An Adaptive Dynamics Vibration Absorber (South Australia: Department of Mechanical Engineering-The University of Adelaide, 1999).

[8] U.S. Deshpande, Recent Advances in Materials for Use in Permanent Magnet Machines: a Review, In Proceedings of IEEE Electric Machines and Drives Conference, IEMDC'03, Madison, United States, 1-4 June 2003, Vol. 1, pp. 509-515, 2003.

[9] Hitachi Metals, 2004. Product Catalogue: HILOP. Available at: http://www.hitachimetals. co.jp/e/prod/prod03/pdf/hg-a17-e.pdf. [cited 10 December 2004]. Available from Hitachi Metals Ltd, Tokyo, Japan.

[10] G.E. Fish, Soft Magnetic Materials, In Proceedings of the IEEE, Vol. 78, No. 6, pp. 947-972, 1990. 